\title{
CIRCULATION AND RESPIRATION DURING AN EPISODE OF CHILL AND FEVER IN MAN ${ }^{1}$
}

\author{
By M. D. ALTSCHULE, A. S. FREEDBERG, ANd M. J. McMANUS \\ (From the Medical Service and Medical Research Laboratories, Beth Israel Hospital, \\ and the Department of Medicine, Harvard Medical School, Boston)
}

(Received for publication July 14, 1945)

Changes in respiratory and circulatory function in patients with fever have been noted by clinicians for many centuries. In recent years a number of investigators have studied respiration and circulation in patients with febrile diseases (1), and many data bearing on these aspects of fever are available. Systematic studies on the reaction of the body to fever in different phases of a febrile reaction, however, have not been published. The present report is based on observations made upon patients experiencing an endogenous febrile reaction, i.e., fever consequent to the introduction of foreign protein or microorganisms into the body. The effects of fever induced by physical means such as heating cabinets, hot baths, infrared radiation and diathermy are discussed elsewhere (1).

\section{MATERIAL AND METHODS}

Studies have been made on 8 subjects ranging in age between 25 and 63 years; 3 of them were women (Cases 1,3 , and 6). All were given fever for therapeutic purposes; the diagnoses included paresis (Case 2), rheumatoid arthritis (Cases $1,3,5,6,7$ ), gonococcal arthritis (Case 4), and lymphedema of the face of unknown origin (Case 8). Fever was induced by means of the injection intravenously of a typhoid vaccine.

All studies were begun with the patients in the basal state; the patients remained in bed, taking no food and only small amounts of water throughout the period of observation on a given day. All measurements, except that of cardiac output, were made with the patient recumbent in bed; the cardiac output was measured with the patient propped up at an angle of about $30^{\circ}$. The pulse and respiratory rates were counted for 1 minute at frequent intervals. Arterial pressures were measured by the auscultatory method. The cardiac output was measured by the method of Starr and Gamble (2), the oxygen consumption, respiratory minute volume, alveolar air carbon dioxide content and respiratory quotient being determined at the same time. The arm-to-tongue circulation time was measured by means of sodium dehydrocholate (3), and the venous pressure was estimated by the

1 This study was aided by a grant from the Josiah Macy, Jr. Foundation. direct method of Moritz and von Tabora (4). Samples of blood taken from the femoral artery and from femoral and antecubital veins without stasis were analyzed for oxygen and carbon dioxide by means of the method of van Slyke and Neill (5) as modified by Fieser (6). The lung volume and its subdivisions were measured by the method of Christie (7), modified somewhat (8), the oxygen consumption being estimated at the same time. The method of Gibson and Evelyn (9) was used for measuring the plasma and blood volumes; the "direct" technique, using repeated injections of dye, and the "indirect" technique, using repeated observations after a single injection, were both employed. An attempt to study the function of lymphatics was made by means of a method suggested by Griffith (10), using the dye T-1824. The small blood vessels of the nailfold were studied by means of a microscope which magnified 100 times after cleansing the skin with xylol and application of liquid petrolatum to the area to be observed. The $\mathrm{pH}$ of the arterial blood was studied by means of a potentiometer with glass electrodes.

\section{OBSERVATIONS}

1. Clinical findings. A febrile episode was found to consist of 4 phases which have been designated: (1) prodrome, (2) chill, (3) flush, and (4) defervescence.

The prodrome began after the injection of the typhoid vaccine, lasted for 30 to 90 minutes and was characterized by a variety of complaints including lassitude, headache, aches and pains, and malaise. The chill phase developed rapidly and manifested itself by increasing pallor, greyish cyanosis, narrowing of all the superficial veins, hyperventilation, the appearance of a few beads of perspiration on the face and, at times, gooseflesh over the extremities also. Nausea occurred in almost all patients and was associated with vomiting in some. The rectal temperature rose, but the skin remained cool; the patients complained of feeling cold and exhibited a strong tendency to shiver. In some experiments this tendency manifested itself only by tensing of the muscles, while in others vigorous rigors occurred. If rigors developed, they could be abated by cov- 
ering the patient, and if not present, they could be precipitated by exposing the patient to a blast of cool air or by placing a small piece of ice in his hand. Urine formation was minimal or absent during the chill phase. The chill phase lasted for approximately an hour and one-half. It could be prevented by the previous administration of antipyretic drugs. The flush phase was characterized by the rapid development of a generalized flush which usually persisted but which might regress

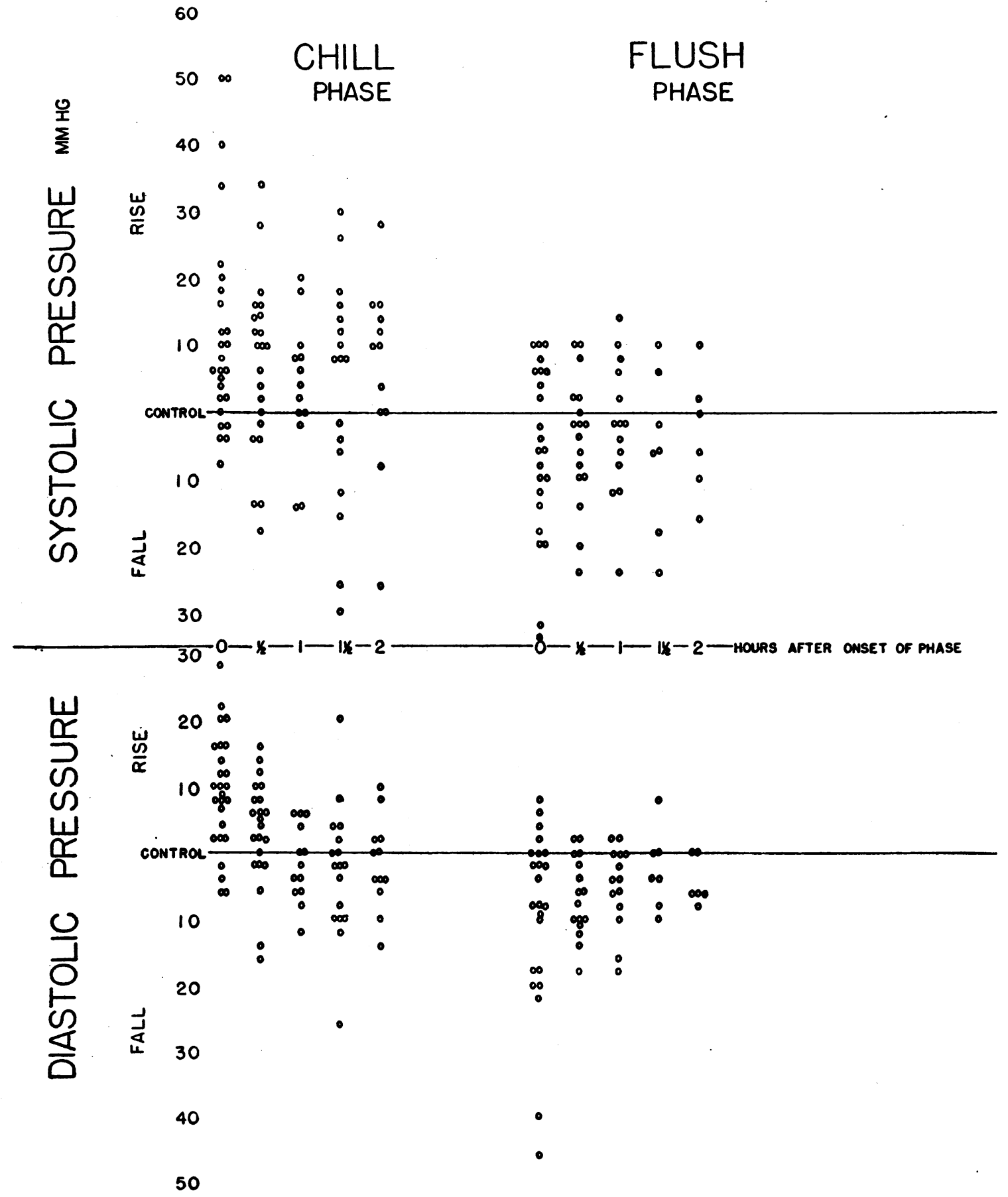

Fig. 1. Changes in Blood Pressure in All Studies during a Febrile Reaction 
somewhat initially before becoming established. The cutaneous veins became greatly dilated. A drenching sweat often developed at or shortly after the appearance of the cutaneous flush, but in patients who had had a severe chill reaction the onset of severe sweating was often delayed for 10 to 20 minutes. At about the time of the establishment of the flush phase the patient complained of feeling warm and the skin felt hot; the rectal temperature remained at a high level with only minor fluctuations. A pounding headache was usually present. Nausea and vomiting were relieved with the onset of the flush phase. The onset of the flush phase was often associated with a diuresis. The flush phase lasted for approximately an hour and then passed gradually into the phase of defervescence when all abnormal findings regressed over a period of several hours. In a few instances, defervescence was interrupted by a second chill phase which instituted another typical febrile cycle.

2. Cutaneous capillary microscopy. No changes in cutaneous circulation occurred during the prodrome. The chill phase was ushered in by the rapid disappearance of most of the capillaries, the few remaining visible capillaries becoming greatly narrowed and containing blood moving abnormally slowly. The columns of blood in the capillaries appeared segmented. The vasoconstriction in some instances was at first variable, but soon became

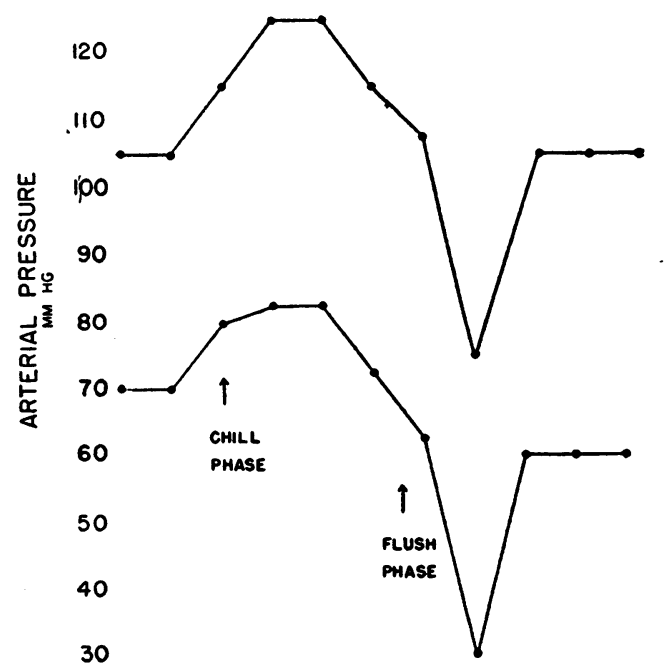

$0 \cdot 1 \cdot 2 \cdot 3 \cdot 4 \cdot 5$ HOURS

Fig. 2. Initial Rise in Arterial Pressure in Chill Phase and Marked Fall in Flush Phase

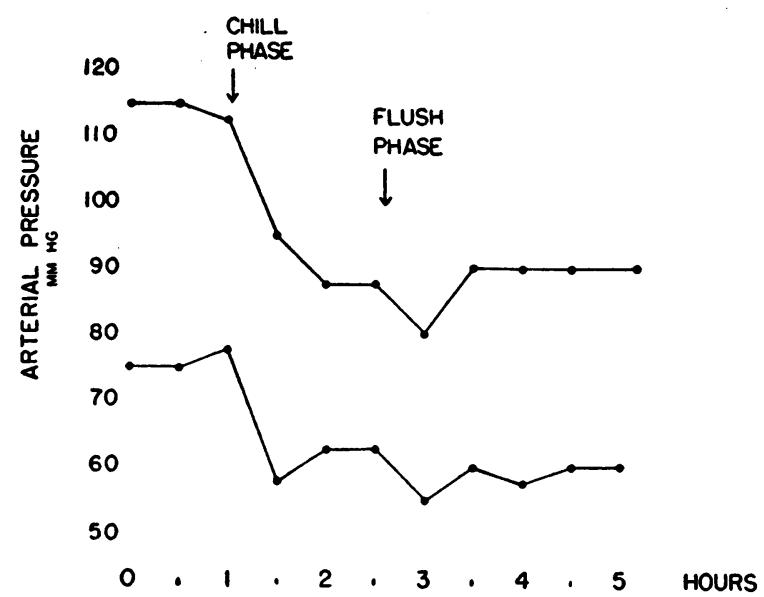

Fig. 3. Fall in Arterial Pressure in Chill Phase and Further Decrease in Flush Phase

marked. In all instances it persisted until the onset of the flush phase. The latter was associated with the rapid appearance of large numbers of widely open capillaries containing blood moving very rapidly. All visible vessels, including arterioles and venules, appeared to pulsate. In some instances the onset of the flush phase was associated with the alternate appearance and regression of vasodilatation for a few minutes until finally the vasodilatation became established. $D e$ fervescence was characterized by a gradual return toward normal.

3. Arterial pressure. No changes occurred during the prodrome. A rise in systolic and diastolic blood pressure usually occurred in the early part of the chill phase, but this rise was not noted in 5 of 26 studies on the arterial pressure. In 7 experiments the arterial pressure fell below the control level late in the chill phase, the maximal decreases being $30 \mathrm{~mm}$. $\mathrm{Hg}$ systolic and $26 \mathrm{~mm}$. $\mathrm{Hg}$ diastolic. The onset of the flush phase was associated with a fall in arterial pressure, the maximal decrease below the control levels being 34 $\mathrm{mm}$. $\mathrm{Hg}$ systolic and $46 \mathrm{~mm}$. $\mathrm{Hg}$ diastolic. The arterial pressure gradually returned to normal during defervescence (Figures 1 to 3 ).

4. Venous pressure. No striking changes occurred, but a tendency toward lowering of the venous pressure became apparent during the chill phase (Table I), with resumption of normal levels during the flush phase.

5. Cardiac output and arteriovenous oxygen difference. The minute volume output of the 
TABLE I

Venous pressure

\begin{tabular}{|c|c|c|c|}
\hline Case & $\begin{array}{c}\text { Venous } \\
\text { pressure }\end{array}$ & Remarks & $\begin{array}{c}\text { Rectal } \\
\text { temperature }\end{array}$ \\
\hline 1 & $\begin{array}{c}\text { cm. of } H=O \\
2.9 \\
2.9 \\
5.9 \\
2.1\end{array}$ & $\begin{array}{l}\text { Control } \\
\text { Early chill } \\
\text { Moderate chill } \\
\text { Moderate flush }\end{array}$ & $\begin{array}{r}{ }^{\circ} F . \\
99.2 \\
99.6 \\
101.3 \\
102.0\end{array}$ \\
\hline 2 & $\begin{array}{l}9.3 \\
3.3 \\
3.1 \\
3.5\end{array}$ & $\begin{array}{l}\text { Control } \\
\text { Early chill } \\
\text { Moderate chill } \\
\text { Moderate flush }\end{array}$ & $\begin{array}{r}99.4 \\
100.1 \\
100.9 \\
104.2\end{array}$ \\
\hline 3 & $\begin{array}{l}6.5 \\
6.0 \\
1.5 \\
2.5\end{array}$ & $\begin{array}{l}\text { Control } \\
\text { Early chill } \\
\text { Severe chill } \\
\text { Moderate flush }\end{array}$ & $\begin{array}{r}99.3 \\
101.7 \\
104.6 \\
105.2\end{array}$ \\
\hline 4 & $\begin{array}{l}3.0 \\
3.9 \\
3.5 \\
2.0\end{array}$ & $\begin{array}{l}\text { Control } \\
\text { Moderate chill } \\
\text { Moderate flush } \\
\text { Defervescence }\end{array}$ & $\begin{array}{r}99.3 \\
103.3 \\
105.7 \\
105.5\end{array}$ \\
\hline 5 & $\begin{array}{l}4.5 \\
1.5 \\
3.5\end{array}$ & $\begin{array}{l}\text { Control } \\
\text { Severe chill } \\
\text { Moderate chill }\end{array}$ & $\begin{array}{r}99.0 \\
99.8 \\
103.4\end{array}$ \\
\hline 7 & $\begin{array}{l}1.5 \\
0.5 \\
1.0\end{array}$ & $\begin{array}{l}\text { Control } \\
\text { Moderate chill } \\
\text { Moderate flush }\end{array}$ & $\begin{array}{r}99.1 \\
101.5 \\
103.5\end{array}$ \\
\hline 8 & $\begin{array}{l}4.7 \\
2.0 \\
1.8 \\
5.0\end{array}$ & $\begin{array}{l}\text { Control } \\
\text { Early chill } \\
\text { Severe chill } \\
\text { Moderate flush }\end{array}$ & $\begin{array}{r}99.1 \\
100.5 \\
101.2 \\
103.5\end{array}$ \\
\hline
\end{tabular}

heart and arteriovenous oxygen difference were normal before the onset of the chill phase in all 6 subjects studied (Table II). Changes in cardiac output were variable during the chill phase, increases occurring in half the cases. However, the increases in cardiac output which occurred were, except in 1 experiment, smaller than expected from the observed changes in oxygen consumption; in 2 of the 3 patients the cardiac output relative to oxygen consumption fell 14 and 15 per cent. In the patients in whom cardiac output did not rise at any time and fell only in the chill phase, the absolute decreases were between 12 and 33 per cent, and the decreases relative to oxygen consumption between 24 and 57 per cent. In the chill phase a variable increase in arteriovenous oxygen difference occurred, ranging from 1 to 131 per cent of the control value. In 5 of the 6 patients the arteriovenous difference increased by 16 per cent or more and in 1 instance a fall occurred. The amount of increase in arteriovenous difference varied roughly with the severity of the chill reaction. In the flush phase all pa- tients exhibited an increase in cardiac output in excess of the rise in oxygen consumption; the absolute increase was between 45 and 182 per cent of the control value and the increase relative to oxygen consumption was between 10 and 86 per cent. The arteriovenous oxygen difference fell in all experiments by 9 to 46 per cent. The changes during the flush phase paralleled roughly the clinical manifestations of the reaction.

6. Circulation time. Slowing of the arm-totongue time occurred during the chill phase in 3 of the 4 patients studied (Table II). The slowing varied roughly with the severity of the chill reaction and ranged between 2 and 13 seconds, or 11 to 100 per cent, of the control level. In 1 of these the circulation time became accelerated somewhat late in the chill phase. The fourth subject showed an acceleration of 3 seconds, or 16 per cent, when studied in the chill phase. During the flush phase the circulation times became accelerated in all instances by 6 to 8.5 seconds, or 28 to 45 per cent of the control value. The changes during the chill and flush phases varied roughly with the severity of the reactions as judged by clinical criteria.

7. Pulse rate. A roughly linear relation existed between rectal temperature and pulse rate (Figure 4). The average rise was approximately 10 beats per degree of fever.

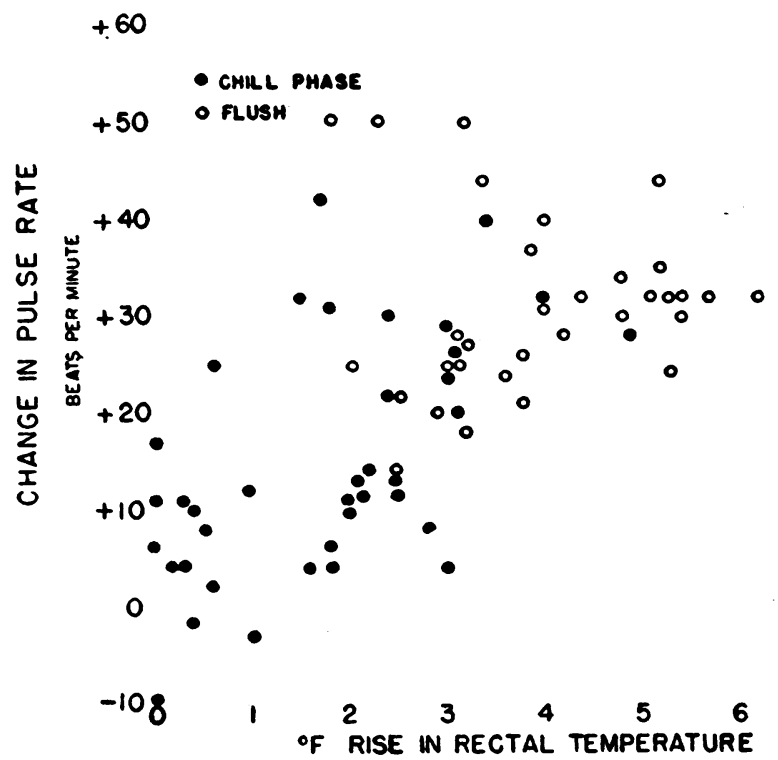

Fig. 4. Changes in Pulse Rate during a Febrile ReAction 
TABLE II

Cardiac output and circulation time

\begin{tabular}{|c|c|c|c|c|c|c|}
\hline Case & Cardi & output & $\begin{array}{l}\text { Arteriovenous } \\
\text { oxygen }\end{array}$ & Circulation time & Remarks & $\begin{array}{c}\text { Rectal } \\
\text { temperature }\end{array}$ \\
\hline 1 & $\begin{array}{c}\text { L. per minute } \\
3.98 \\
3.95 \\
4.41 \\
5.78 \\
5.05\end{array}$ & $\begin{array}{c}\text { L. per } 100 \mathrm{ml} \text {. of } \\
\text { O. consumed } \\
1.74 \\
1.72 \\
1.82 \\
2.29 \\
1.90\end{array}$ & $\begin{array}{c}\text { volumes per cent } \\
5.77 \\
5.80 \\
5.49 \\
4.36 \\
5.24\end{array}$ & $\begin{array}{l}\text { seconds } \\
18 \\
20 \\
14 \\
12 \\
14\end{array}$ & $\begin{array}{l}\text { Control } \\
\text { Early mild chill } \\
\text { Late mild chill } \\
\text { Moderate flush } \\
\text { Defervescence }\end{array}$ & $\begin{array}{r}{ }^{\circ} F . \\
98.9 \\
99.6 \\
101.9 \\
102.8 \\
102.0\end{array}$ \\
\hline 3 & $\begin{array}{l}3.66 \\
2.74 \\
5.88\end{array}$ & $\begin{array}{l}1.81 \\
1.21 \\
2.20\end{array}$ & $\begin{array}{l}5.52 \\
8.25 \\
4.54\end{array}$ & $\begin{array}{l}13 \\
26\end{array}$ & $\begin{array}{l}\text { Control } \\
\text { Moderate chill } \\
\text { Moderate flush }\end{array}$ & $\begin{array}{r}99.3 \\
102.5 \\
104.0\end{array}$ \\
\hline 4 & $\begin{array}{r}4.46 \\
3.92 \\
2.89 \\
12.58\end{array}$ & $\begin{array}{l}1.66 \\
1.27 \\
0.72 \\
3.09\end{array}$ & $\begin{array}{r}6.02 \\
7.84 \\
13.93 \\
3.21\end{array}$ & $\begin{array}{l}19.5 \\
25 \\
31 \\
14\end{array}$ & $\begin{array}{l}\text { Control } \\
\text { Moderate chill } \\
\text { Severe chill } \\
\text { Severe flush }\end{array}$ & $\begin{array}{r}99.3 \\
103.6 \\
105.6 \\
104.2\end{array}$ \\
\hline 6 & $\begin{array}{l}3.54 \\
3.92 \\
6.90\end{array}$ & $\begin{array}{l}1.73 \\
1.47 \\
2.34\end{array}$ & $\begin{array}{l}5.73 \\
6.79 \\
4.26\end{array}$ & & $\begin{array}{l}\text { Control } \\
\text { Mild chill } \\
\text { Moderate flush }\end{array}$ & $\begin{array}{r}98.0 \\
102.0 \\
104.3\end{array}$ \\
\hline 7 & $\begin{array}{l}3.81 \\
3.07 \\
6.78\end{array}$ & $\begin{array}{l}1.58 \\
1.00 \\
2.10\end{array}$ & $\begin{array}{l}6.33 \\
9.81 \\
4.75\end{array}$ & & $\begin{array}{l}\text { Control } \\
\text { Severe chill } \\
\text { Moderate flush }\end{array}$ & $\begin{array}{r}98.7 \\
103.3 \\
103.8\end{array}$ \\
\hline 8 & $\begin{array}{l}5.15 \\
5.45 \\
8.01\end{array}$ & $\begin{array}{l}2.13 \\
1.83 \\
2.34\end{array}$ & $\begin{array}{l}4.71 \\
5.47 \\
4.28\end{array}$ & $\begin{array}{l}19 \\
16 \\
10.5\end{array}$ & $\begin{array}{l}\text { Control } \\
\text { Mild chill } \\
\text { Moderate flush }\end{array}$ & $\begin{array}{r}98.7 \\
102.0 \\
103.7\end{array}$ \\
\hline
\end{tabular}

8. Oxygen consumption. In the absence of rigors or muscle tensing in the patients, the oxygen consumption varied roughly with the rectal temperature (Figure 5). The average rise in oxygen

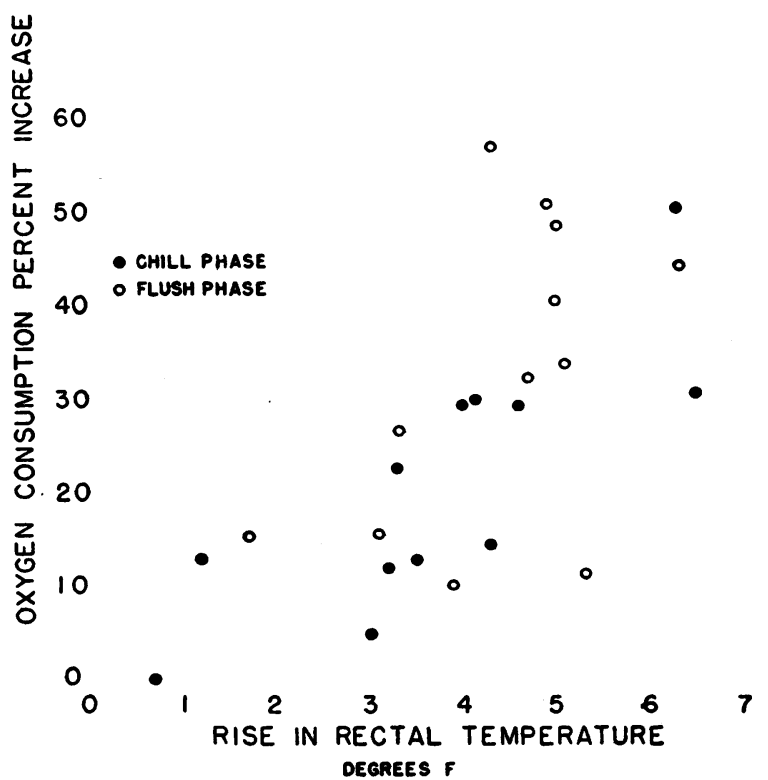

Fig. 5. InCrease in Oxygen Consumption during a Febrile Reaction consumption was approximately 7 per cent per degree of fever.

9. Respiratory minute volume. The respiratory minute volume rose during both the chill and flush phases (Table III). During the chill phase the hyperventilation exceeded the rise in oxygen consumption, while during the flush phase the respiratory volume relative to oxygen consumption per minute fell to or toward normal.

10. Respiratory rate and tidal air. The respiratory rate increased somewhat more than the minute volume during the chill phase, so that the tidal air fell slightly (Table III). During the fush phase the rate of respiration fell relative to the respiratory minute volume, and the tidal air volume rose to or somewhat above normal in all instances but 1 (Case 6).

11. Respiratory quotient. The respiratory quotient was between 0.78 and 0.83 before the body temperature rose. It was between 0.80 and 1.03 in the chill phase and between 0.81 and 0.86 in the flush phase.

12. Alveolar air carbon dioxide content. The alveolar air carbon dioxide content was between 5.0 and 5.6 per cent in the control and prodromal 
periods (Table III). It fell to 3.9 to 5.2 per cent in the chill and was between 4.7 and 4.9 per cent in the flush phase.

13. Subdivisions of the lung volume. The functional residual (subtidal) air was increased by 2 to 24 per cent in the chill phase, the average increase being 12 per cent; in only 2 patients was the increase larger than the error of the method (Table IV). In the flush phase and defervescence the increases were between 1 and 16 per cent and

TABLE III

Respiratory dynamics

\begin{tabular}{|c|c|c|c|c|c|c|c|}
\hline Case & Respiratory rate & Tidal air & Respirat & y volume & Alveolar $\mathrm{CO}_{2}$ & Remarks & $\begin{array}{c}\text { Rectal } \\
\text { tem- }\end{array}$ \\
\hline 1 & $\begin{array}{c}\text { per minute } \\
13 \\
17 \\
23 \\
18 \\
15.5\end{array}$ & $\begin{array}{l}m l . \\
414 \\
325 \\
317 \\
400 \\
427\end{array}$ & $\begin{array}{c}\text { L. per minute } \\
\mathbf{5 . 3 8} \\
\mathbf{5 . 5 2} \\
\mathbf{7 . 2 9} \\
\mathbf{7 . 2 0} \\
\mathbf{6 . 6 2}\end{array}$ & $\begin{array}{c}L . \text { per } 100 \text { ml. } \\
\text { of } O_{2} \text { consumed } \\
2.35 \\
2.41 \\
3.01 \\
2.86 \\
2.50\end{array}$ & $\begin{array}{c}\text { per cent } \\
5.3 \\
5.2 \\
4.7 \\
4.6 \\
4.6\end{array}$ & $\begin{array}{l}\text { Control } \\
\text { Early mild chill } \\
\text { Mild chill } \\
\text { Moderate flush } \\
\text { Defervescence }\end{array}$ & $\begin{array}{r}\circ F . \\
98.9 \\
99.6 \\
101.9 \\
102.8 \\
102.0\end{array}$ \\
\hline 3 & $\begin{array}{l}16 \\
21 \\
19\end{array}$ & $\begin{array}{l}328 \\
309 \\
349\end{array}$ & $\begin{array}{l}5.25 \\
6.50 \\
6.63\end{array}$ & $\begin{array}{l}2.60 \\
2.88 \\
2.47\end{array}$ & $\begin{array}{l}5.5 \\
5.0 \\
4.9\end{array}$ & $\begin{array}{l}\text { Control } \\
\text { Moderate chill } \\
\text { Moderate flush }\end{array}$ & $\begin{array}{r}99.3 \\
102.5 \\
104.0\end{array}$ \\
\hline 4 & $\begin{array}{l}12 \\
18.5 \\
18 \\
16.5\end{array}$ & $\begin{array}{l}635 \\
491 \\
520 \\
683\end{array}$ & $\begin{array}{r}7.62 \\
9.09 \\
9.37 \\
11.27\end{array}$ & $\begin{array}{l}2.84 \\
2.96 \\
2.32 \\
2.79\end{array}$ & $\begin{array}{l}5.0 \\
4.2 \\
4.3 \\
4.3\end{array}$ & $\begin{array}{l}\text { Control } \\
\text { Moderate chill } \\
\text { Severe chill } \\
\text { Severe flush }\end{array}$ & $\begin{array}{l}99.3 \\
103.6 \\
105.6 \\
104.2\end{array}$ \\
\hline 6 & $\begin{array}{l}10 \\
25 \\
19\end{array}$ & $\begin{array}{l}457 \\
261 \\
343\end{array}$ & $\begin{array}{l}4.57 \\
6.51 \\
6.51\end{array}$ & $\begin{array}{l}2.23 \\
2.45 \\
2.22\end{array}$ & $\begin{array}{l}5.6 \\
4.6 \\
4.8\end{array}$ & $\begin{array}{l}\text { Control } \\
\text { Mild chill } \\
\text { Moderate flush }\end{array}$ & $\begin{array}{r}98.0 \\
102.0 \\
104.3\end{array}$ \\
\hline 7 & $\begin{array}{l}13 \\
23 \\
19\end{array}$ & $\begin{array}{l}525 \\
518 \\
624\end{array}$ & $\begin{array}{r}6.81 \\
12.41 \\
11.56\end{array}$ & $\begin{array}{l}2.83 \\
3.97 \\
3.59\end{array}$ & $\begin{array}{l}5.5 \\
3.9 \\
4.1\end{array}$ & $\begin{array}{l}\text { Control } \\
\text { Severe chill } \\
\text { Moderate flush }\end{array}$ & $\begin{array}{r}98.7 \\
103.3 \\
103.8\end{array}$ \\
\hline 8 & $\begin{array}{l}12.5 \\
17 \\
16\end{array}$ & $\begin{array}{l}516 \\
505 \\
578\end{array}$ & $\begin{array}{l}6.45 \\
9.09 \\
9.25\end{array}$ & $\begin{array}{l}2.65 \\
3.05 \\
2.70\end{array}$ & $\begin{array}{l}5.1 \\
4.2 \\
4.5\end{array}$ & $\begin{array}{l}\text { Control } \\
\text { Mild chill } \\
\text { Moderate flush }\end{array}$ & $\begin{array}{r}98.7 \\
102.0 \\
103.7\end{array}$ \\
\hline
\end{tabular}

TABLE IV

Subdivisions of the lung volume

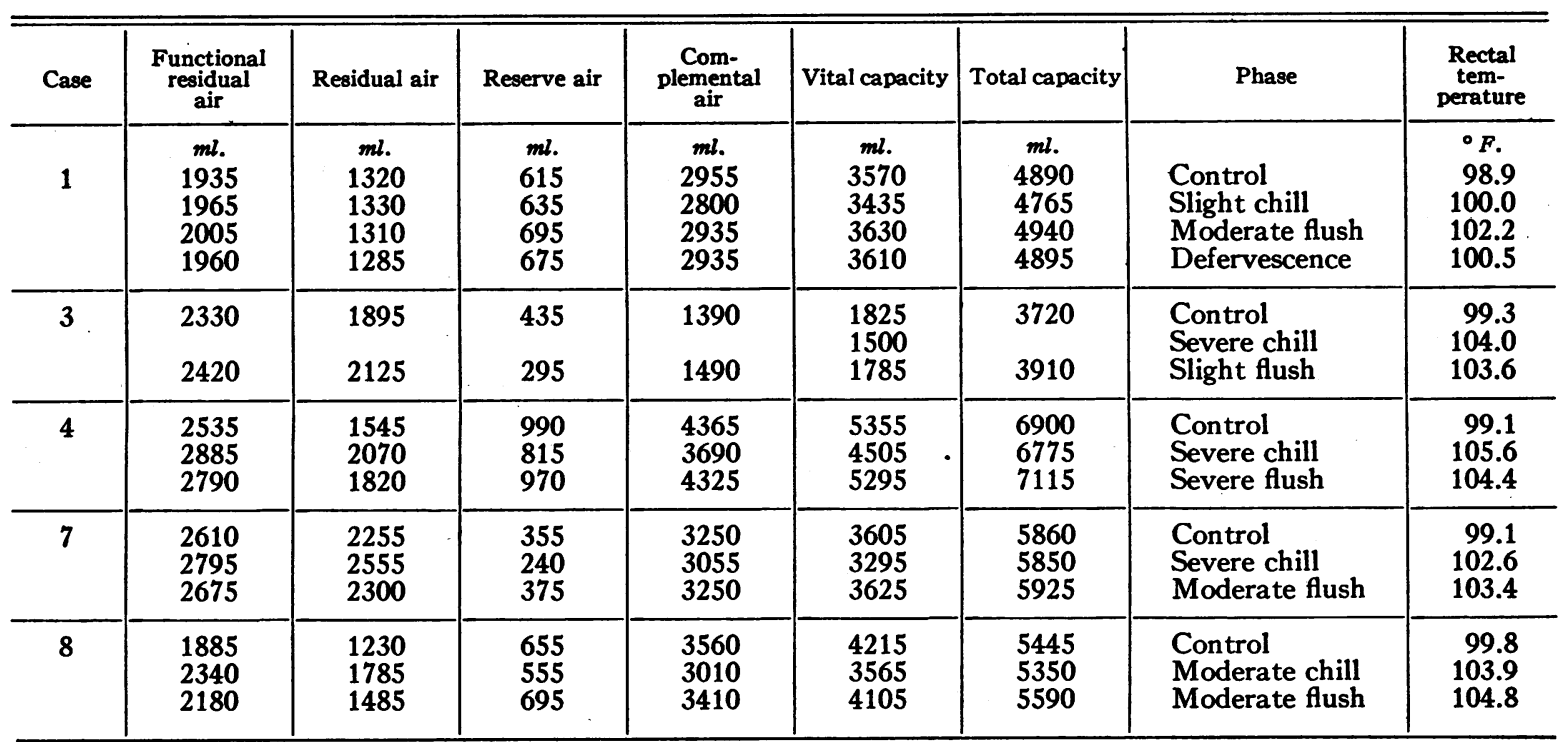


TABLE V

Blood oxygen and carbon diaxide content

\begin{tabular}{|c|c|c|c|c|c|c|c|}
\hline \multirow{2}{*}{ Case } & \multicolumn{3}{|c|}{ Arterial blood } & \multicolumn{2}{|c|}{ Venous blood } & \multirow{2}{*}{$\begin{array}{c}\text { Rectal } \\
\text { temperature }\end{array}$} & \multirow{2}{*}{ Remarks } \\
\hline & $\begin{array}{l}\text { Oxygen } \\
\text { content }\end{array}$ & $\begin{array}{c}\text { Oxygen } \\
\text { saturation }\end{array}$ & $\begin{array}{c}\text { Carbon dioxide } \\
\text { content }\end{array}$ & $\begin{array}{l}\text { Oxygen } \\
\text { content }\end{array}$ & $\begin{array}{c}\text { Carbon dioxide } \\
\text { content }\end{array}$ & & \\
\hline 1 & $\begin{array}{c}\text { per cent } \\
15.23 \\
15.43 \\
15.29\end{array}$ & $\begin{array}{c}\text { per cent } \\
100 \\
94 \\
99\end{array}$ & $\begin{array}{l}\text { per cent } \\
44.68 \\
40.52 \\
41.11\end{array}$ & $\begin{array}{c}\text { per cent } \\
11.48 \\
9.92 \\
5.93 \\
14.79 \\
13.59\end{array}$ & $\begin{array}{l}\text { per cent } \\
47.39 \\
46.45 \\
39.09 \\
41.78 \\
42.72\end{array}$ & $\begin{array}{l}{ }^{\circ} F . \\
99.7 \\
100.5 \\
102.0 \\
102.4 \\
103.4 \\
104.5\end{array}$ & $\begin{array}{l}\text { Control } \\
\text { Early chill } \\
\text { Moderate chill } \\
\text { Moderate chill } \\
\text { Moderate flush } \\
\text { Moderate flush } \\
\text { Defervescence }\end{array}$ \\
\hline 2 & $\begin{array}{l}18.32 \\
19.80 \\
19.07\end{array}$ & $\begin{array}{r}94 \\
100 \\
98\end{array}$ & $\begin{array}{l}43.43 \\
41.25 \\
40.01\end{array}$ & $\begin{array}{r}12.72^{*} \\
7.32^{*} \\
9.97^{*} \\
16.92\end{array}$ & $\begin{array}{l}48.68 \\
49.23 \\
48.25 \\
41.08\end{array}$ & $\begin{array}{r}99.0 \\
100.1 \\
102.7 \\
104.2\end{array}$ & $\begin{array}{l}\text { Control } \\
\text { Early chill } \\
\text { Moderate chill } \\
\text { Moderate flush }\end{array}$ \\
\hline 3 & $\begin{array}{l}19.96 \\
20.32\end{array}$ & $\begin{array}{l}94 \\
96\end{array}$ & $\begin{array}{l}41.30 \\
33.50\end{array}$ & $\begin{array}{r}14.64 \\
4.89 \\
\\
15.70 \\
16.93\end{array}$ & $\begin{array}{l}42.55 \\
46.90 \\
\\
36.32 \\
39.00\end{array}$ & $\begin{array}{r}99.6 \\
101.1 \\
103.6 \\
104.7 \\
103.7\end{array}$ & $\begin{array}{l}\text { Control } \\
\text { Severe chill } \\
\text { Severe chill } \\
\text { Moderate flush } \\
\text { Defervescence }\end{array}$ \\
\hline 4 & $\begin{array}{l}18.63 \\
18.25\end{array}$ & $\begin{array}{l}90 \\
88\end{array}$ & $\begin{array}{l}42.95 \\
35.06\end{array}$ & $\begin{array}{r}10.23 \\
4.10 \\
9.51 \\
13.31\end{array}$ & $\begin{array}{l}49.41 \\
49.60 \\
46.25 \\
44.84\end{array}$ & $\begin{array}{r}99.2 \\
102.5 \\
104.8 \\
104.1\end{array}$ & $\begin{array}{l}\text { Control } \\
\text { Severe chill } \\
\text { Early flush } \\
\text { Severe flush }\end{array}$ \\
\hline 5 & $\begin{array}{l}20.14 \\
20.00 \\
19.20\end{array}$ & $\begin{array}{l}93 \\
93 \\
89\end{array}$ & $\begin{array}{l}46.54 \\
40.65 \\
40.88\end{array}$ & $\begin{array}{r}15.23 \\
8.07 \\
17.65\end{array}$ & $\begin{array}{l}50.55 \\
47.16 \\
44.43\end{array}$ & $\begin{array}{r}98.6 \\
101.6 \\
105.0\end{array}$ & $\begin{array}{l}\text { Control } \\
\text { Severe chill } \\
\text { Moderate flush }\end{array}$ \\
\hline 6 & $\begin{array}{l}16.54 \\
15.06\end{array}$ & $\begin{array}{l}94 \\
86\end{array}$ & $\begin{array}{l}56.04 \\
50.87\end{array}$ & $\begin{array}{r}10.65 \\
9.88 \\
12.14\end{array}$ & $\begin{array}{l}60.95 \\
55.85 \\
54.87\end{array}$ & $\begin{array}{r}98.0 \\
102.0 \\
102.6\end{array}$ & $\begin{array}{l}\text { Control } \\
\text { Mild chill } \\
\text { Moderate flush }\end{array}$ \\
\hline 7 & & & & $\begin{array}{c}13.55 \\
6.34 \\
9.33 \\
8.94^{*} \\
9.25 \\
15.47 \\
12.38^{*}\end{array}$ & $\begin{array}{l}47.08 \\
49.49 \\
47.08 \\
46.30 \\
44.30 \\
40.78 \\
44.15\end{array}$ & $\begin{array}{r}98.3 \\
99.1 \\
101.4 \\
101.4 \\
103.7 \\
104.1 \\
102.1\end{array}$ & $\begin{array}{l}\text { Control } \\
\text { Early severe chill } \\
\text { Severe chill } \\
\text { Severe chill } \\
\text { Severe chill } \\
\text { Moderate flush } \\
\text { Defervescence }\end{array}$ \\
\hline
\end{tabular}

* Femoral venous blood.

averaged 7 per cent. The volume of the residual air was somewhat increased during the febrile reaction in 4 of the 5 patients studied. During the chill phase the increases ranged between 1 and 45 per cent of the original values and averaged 23 per cent. It was outside the range of error of the method in all cases but one. During the flush phase the changes ranged between minus 3 and plus 21 per cent, averaging plus 10 per cent. The reserve (supplemental) air fell in 4 patients, the decreases ranging between 15 and 32 per cent in the chill phase and rose 13 per cent in 1 case. The average change was minus 13 per cent. In the flush phase no consistent change occurred. The complemental air was also diminished by 5 to 15 per cent, averaging 10 per cent, in the chill and showed no consistent change in the flush phase. The decreases in vital capacity were 0 to 18 per cent, averaging 11 per cent, in the chill phase; no consistent change occurred in the flush phase. The total lung volume showed no significant change at any time.

14. Arterial blood gases. Striking changes in arterial blood oxygen concentration did not occur in the patients studied; slight decreases in saturation were found in 2 who hyperventilated markedly (Table V). The arterial blood carbon dioxide concentration showed a considerable fall during the chill with little or no further change in the flush phase. 
15. Venous blood gases. During the chill phase a fall in venous blood oxygen content, ranging between 0.77 and 9.71 volumes per cent, was observed; the amount of fall appeared to vary with the severity of the chill reaction (Table $\mathrm{V})$. In the flush phase the venous blood oxygen content rose to levels 1.49 to 4.20 volumes per cent above the control values and approached the concentrations found in the arterial blood. The venous blood carbon dioxide content was variable during the chill phase, but fell in the flush phase by 3.16 to 7.60 volumes per cent below the control values. A return toward normal occurred during defervescence.

16. Arterial $p H$. Changes in the direction of alkalosis occurred in all patients studied (Table

TABLE VI

Arterial blood $p H$

\begin{tabular}{|c|c|c|c|}
\hline Case & $\mathrm{pH}$ & Remarks & $\begin{array}{c}\text { Rectal } \\
\text { temperature }\end{array}$ \\
\hline 4 & $\begin{array}{l}7.35 \\
7.42 \\
7.44 \\
7.39\end{array}$ & $\begin{array}{l}\text { Control } \\
\text { Chill } \\
\text { Flush } \\
\text { Defervescence }\end{array}$ & $\begin{array}{r}{ }^{\circ} F . \\
99.3 \\
101.3 \\
104.7 \\
103.7\end{array}$ \\
\hline 5 & $\begin{array}{l}7.33 \\
7.44\end{array}$ & $\begin{array}{l}\text { Control } \\
\text { Chill }\end{array}$ & $\begin{array}{r}98.6 \\
102.2\end{array}$ \\
\hline 7 & $\begin{array}{l}7.50 \\
7.60 \\
7.65\end{array}$ & $\begin{array}{l}\text { Control } \\
\text { Early chill } \\
\text { Late chill }\end{array}$ & $\begin{array}{r}99.6 \\
100.7 \\
103.0\end{array}$ \\
\hline
\end{tabular}

TABLE VII

Measurements of hematocrit and plasma volume

\begin{tabular}{c|c|c|l|c}
\hline \hline Case & $\begin{array}{c}\text { Hemato- } \\
\text { crit }\end{array}$ & $\begin{array}{c}\text { Plasma } \\
\text { volume }\end{array}$ & \multicolumn{1}{|c}{ Remarks } & $\begin{array}{c}\text { Rectal tem- } \\
\text { perature }\end{array}$ \\
\cline { 2 - 4 } 1 & $\begin{array}{c}\text { percentage } \\
\text { of cells }\end{array}$ & $m l$. & & $\circ F$. \\
& 45 & 2800 & Control & 100.0 \\
& 45 & 2820 & Early chill & 100.5 \\
& 45 & 2800 & Moderate chill & 102.8 \\
& 45 & 2950 & Moderate flush & 103.5 \\
\hline 4 & 42 & 3475 & Control & 99.4 \\
& 42 & 3475 & Prodrome & 99.4 \\
& 43 & 3395 & Early chill & 102.4 \\
& 44 & 3175 & Moderate chill & 102.9 \\
& 43 & 3210 & Severe flush & 105.5 \\
& 43 & 3560 & Defervescence & 103.4 \\
\hline 5 & 38 & 4310 & Control & 98.6 \\
& 39.5 & 4300 & Prodrome & 98.6 \\
& 41 & 4170 & Moderate chill & 103.0 \\
& 39 & 4195 & Moderate flush & 103.9 \\
\hline 8 & 41 & 2810 & Control & 99.1 \\
& 40.5 & 2910 & Severe chill & 102.0 \\
\hline
\end{tabular}

TABLE VIII

Lymphatic function

\begin{tabular}{|c|c|c|c|c|c|c|}
\hline \multirow{2}{*}{ Case } & \multicolumn{2}{|c|}{ Area stained } & \multirow{2}{*}{ Time } & \multirow{2}{*}{ Streamers } & \multirow{2}{*}{ Remarks } & \multirow{2}{*}{$\begin{array}{l}\text { Rectal } \\
\text { tem- } \\
\text { pera- } \\
\text { ture }\end{array}$} \\
\hline & Initial & Final & & & & \\
\hline 7 & $\begin{array}{c}m m . \\
5 \times 5 \\
6 \times 6 \\
5 \times 5 \\
2 \times 3\end{array}$ & $\begin{array}{l}m m . \\
6 \times 6 \\
6 \times 8 \\
7 \times 7 \\
7 \times 6\end{array}$ & $\begin{array}{c}\text { minutes } \\
20 \\
20 \\
20 \\
3\end{array}$ & $\begin{array}{c}0 \\
0 \\
0 \\
+++t\end{array}$ & $\begin{array}{l}\text { Control } \\
\text { Prodrome } \\
\text { Chill } \\
\text { Flush }\end{array}$ & $\begin{array}{r}\circ F . \\
99.4 \\
99.4 \\
100.8 \\
102.4\end{array}$ \\
\hline 8 & $\begin{array}{l}5 \times 5 \\
5 \times 4 \\
5 \times 4\end{array}$ & $\begin{array}{l}6 \times 6 \\
5 \times 6 \\
8 \times 7\end{array}$ & $\begin{array}{r}20 \\
20 \\
4\end{array}$ & $\begin{array}{c}0 \\
0 \\
++++\end{array}$ & $\begin{array}{l}\text { Control } \\
\text { Chill } \\
\text { Flush }\end{array}$ & $\begin{array}{r}98.7 \\
102.0 \\
103.5\end{array}$ \\
\hline
\end{tabular}

VI). During the chill phase and in the absence of rigors, the $\mathrm{pH}$ rose 0.07 to 0.15 . In the flush phase it was still elevated and fell during defervescence.

17. Blood volume. No changes in plasma volume or hematocrit occurred during the febrile episode (Table VII).

18. Lymphatic function. Wheals on the forearm containing the blue dye increased in size by 75 to 100 per cent slowly during a 20-minute period during the control period (Table VIII). Wheals made during the chill phase increased by the same amount or a little less. During the flush phase, however, a great increase in the size of the wheal occurred within 3 to 5 minutes; streamers radiating out from the wheal also became visible.

\section{DISCUSSION}

The clinical features of the various phases of a febrile reaction have long been recognized in a variety of infectious processes. Patients in whom a foreign protein has been injected pass through the entire course of the febrile reaction within a period of hours, so that comparative studies during the various phases may be made readily and with a minimum of variation consequent to uncontrolled extraneous factors. The endogenous febrile reaction studied under these circumstances gives rise to a series of clinical and physiological changes which occur in regular sequence and fall into uniform patterns.

The significance of the prodromal period is not clear, nor are the mechanisms which act during it clearly understood. This phase is characterized by such non-specific complaints as headache, malaise, and lassitude; detectable changes in car- 
diovascular and respiratory dynamics do not occur. It is terminated by the onset of marked generalized vasoconstriction which is evident in the skin and assumed elsewhere because of the observed changes in arterial blood pressure. The narrowing or disappearance of cutaneous capillaries and the sluggish cutaneous flow observed here, and previously by others, was ascribed to marked arteriolar constriction $(11,12,13)$. The conclusion that capillary blood pressure is unchanged during the chill phase of malaria (14) cannot be accepted because of the fact that the indirect method used is inaccurate. The elevation of arterial blood pressure which occurred in some of the experiments of the present study, as well as in those of other authors (14 to 17 ), indicates that arteriolar narrowing is widespread. More marked and persistent increases in arterial blood pressure would probably develop if it were not for the occurrence of changes in cardiac output which tend to lower arterial pressure. Not only are capillaries and arterial vessels constricted, but the visible veins also become markedly narrowed. It appears, therefore, that the vasoconstriction is a widespread phenomenon involving all vascular elements. On the other hand, some areas within the body probably do not participate in the fairly generalized vasoconstriction and indeed may be the seat of vasodilatation, for the circulating blood volume shows no change as measured here and as previously described (18). Studies on visceral circulation in an endogenous febrile reaction are scanty. A decrease in the size of the kidneys has been described (19) in animals in which a febrile reaction was induced, so that these organs are probably the site of vasoconstriction. Other authors have found a decrease in cerebral (20) and in renal (16) flow in the chill phase of induced febrile reactions. On the other hand, the findings of the present study which show an increase in the residual air volume and in the ratio of residual air volume to total pulmonary capacity in the chill phase suggest that some degree of pulmonary congestion may occur.

During the chill phase the cardiac output fell in some experiments and in the rest failed to rise in proportion to the increase in metabolic rate which occurred as the body temperature rose. This phenomenon was paralleled by increases in arteriovenous oxygen difference and by decreased oxygen content of venous blood taken from the antecubital or femoral veins. None of the findings suggested direct depression of cardiac function as the cause of the observed absolute or relative decrease in minute volume output, i.e., bradycardia did not occur and the venous pressure did not rise. The tachycardia likewise did not reach levels which might cause lowering of the cardiac output. It is probable that the changes in cardiac output which occurred in the chill phase in the patients studied were the resultant of 2 opposing forces: (1) a tendency to increase parallel with the rising metabolic rate associated with fever; and (2) a tendency to decrease as a consequence of impairment of venous return due to intense vasoconstriction. In regard to the latter, it is of interest that the venous pressure tended to fall somewhat during the chill phase. One worker (14) had found no change in venous pressure during the chill phase of a malarial paroxysm. The arm-to-tongue circulation time was slowed early in the chill phase in every patient. Late in this phase, the circulation time in some patients became somewhat accelerated, while in others it remained slow. The initial slowing was probably consequent largely or entirely to slow flow secondary to cutaneous vasoconstriction, for cooling the skin has been shown to slow the arm-to-tongue time (21). During the early part of the chill phase changes in cardiac output are probably minimal or absent. Later in this period, however, the cardiac output may fall and when it does so, the circulation time becomes more prolonged. It is not possible to state how much of the prolongation in such instances is the effect of cutaneous vasoconstriction in the arm per se and how much is the consequence of diminished cardiac output.

Changes in respiration during the chill phase consist in increased respiratory minute volumes greatly in excess of increases in oxygen consumption due to the fever. There were also exaggerated increases in respiratory rate which resulted in slight or moderate decreases in tidal air volume. Several mechanisms may be responsible for the excessive hyperventilation of the chill phase. The above-described cutaneous vasoconstriction limits heat dispersal via the skin $(22,23)$, so that the effects of increased heat production are exaggerated and the body temperature rises rapidly. Increased temperatures within the brain give rise 
to hyperventilation (24 to 27), presumably in an attempt to lower body temperature. Another factor which may increase respiratory minute volume out of proportion to metabolic requirements is the stasis which occurs when the cardiac output falls or at least fails to rise in proportion to oxygen consumption. Some degree of tissue anoxia is present in all such instances and in some experiments a rise in venous blood carbon dioxide also occurred. A third mechanism favoring-excessive hyperventilation might be reflexes activated by pulmonary congestion. The importance of each of these causative factors cannot be evaluated. The respiratory changes which occurred in the chill phase resulted in a lowering of alveolar air carbon dioxide content and blowing off of appreciable amounts of carbon dioxide from the blood. The arterial blood carbon dioxide was significantly lowered, while the changes in the venous blood were the resultant of 2 opposing factors: (1) lowering of blood carbon dioxide consequent to hyperventilation; and (2) elevation of blood carbon dioxide consequent to stasis. Studies of respiratory quotient showed a tendency toward the giving off of larger amounts of carbon dioxide than in the basal state, but this was not definitely consequent solely to hyperventilation, since increased metabolism of carbohydrate also occurs. The loss of carbon dioxide from the blood gave rise to a tendency toward alkalosis; that alkalosis was not more marked is probably a consequence of the elevation of blood lactate and pyruvate levels which occurs in fever (28).

The marked generalized vasodilatation which characterized the flush phase presumably involved all vascular elements. Microscopy revealed the capillaries of the skin to be markedly increased in number and size and direct inspection showed the superficial veins to be dilated. Arteriolar dilatation probably also was present, for some fall in arterial blood pressure and the appearance of capillary dilatation occurred regularly. In addition, arteriovenous shunts probably became patent, for venous blood became arterialized, often markedly so. The slight rise in venous pressure which was noted might also have been consequent to opening of arteriovenous channels. Nevertheless, vascular constriction must have occurred somewhere in the body, for the circulating blood volume was unchanged. Increases in cardiac output in the flush phase were out of proportion to the metabolic needs, and the arm-to-tongue time was greatly accelerated. The renal flow may also increase in the flush phase $(16,19,30)$. These phenomena may have been consequent, at least in part, to increased venous return secondary to opening of the arteriovenous shunts. Another factor making for this increase in cardiac output is elevated cerebral temperature (25). The absence of stasis in the flush phase and the restoration of 1 of the mechanisms for heat dispersal lost in the chill phase, i.e., increased circulation through the skin, removes 2 factors which exaggerate the hyperventilation of the chill phase. Diminished pulmonary congestion has the same effect. Accordingly, the respiratory minute volume is lowered relative to oxygen consumption and returns to or toward a normal relation with metabolic rate. Loss of carbon dioxide from the arterial blood and alkalosis, therefore, do not progress.

A state which had the clinical characteristics of shock developed in patients in whom the severest chill reactions occurred. The patients were pale, cold, sweaty, anxious, and dyspneic; they showed tachycardia and a falling arterial blood pressure. Physiological studies made at this time revealed very low cardiac output, marked deoxygenation of venous blood, and a fall in venous pressure. This state differed from that seen in other types of shock in that blood volume, oxygen consumption, and rectal temperature did not fall; the syndrome was, in addition, selflimited. The clinical manifestations of shock were in some experiments temporarily exaggerated at the onset of the flush phase when vasodilatation rapidly developed.

The observations on lymphatic function made here are difficult to interpret. It appears that lymphatic flow is increased in the flush phase of the febrile reaction, but the mechanisms responsible for this change are difficult to evaluate. Vasodilatation and elevated capillary pressure tend to increase filtration from the blood. The former obviously occurs and the latter may also. A rise in capillary pressure when the skin is heated locally has been demonstrated (31). Whether such a rise can also occur in a febrile reaction when vasodilatation is generalized and may be extreme cannot be determined. 
The factors which initiate the febrile reaction and determine its phases are not clearly understood. The cause of the increased heat production which occurs in a febrile reaction is probably related in some way to hypothalamic function, for damage to that area prevents it (32). Similarly, the vasomotor manifestations of the febrile reaction appear to be initiated by the hypothalamus. The onset of flushing and sweating occurs at a higher level in patients undergoing a febrile reaction than in subjects exposed to warm environmental temperatures and, accordingly, it appears that thermostatic control of the peripheral vascular and sweating mechanisms is reset at a higher than normal level in endogenous fever.

\section{SUMMARY AND CONCLUSIONS}

1. Changes in circulation and respiration have been studied in 8 patients following the injection intravenously of typhoid vaccine.

2. The febrile reaction consisted of 4 phases: (a) prodrome, (b) chill, (c) flush, (d) defervescense. Each had distinctive clinical features and, except for the prodrome, each was characterized by a definite series of physiological phenomena.

3. The chill phase was characterized by intense vasoconstriction, decreased cardiac output, slowed circulation time, hyperventilation, alkalosis, and oliguria. There was an initial hypertension followed by hypotension and, in some experiments, the development of shock.

4. The flush phase was characterized by marked vasodilatation, drenching swẹts, increased cardiac output, accelerated circulation time, a lesser degree of hyperventilation, maintained alkalosis, diuresis, and in many experiments a sudden fall in blood pressure at the onset of the phase.

5. Defervescence was characterized by a return of all mechanisms toward normal.

6. Lymphatic function was apparently increased in the flush phase.

7. No change in circulating plasma volume occurred during any phase of the febrile reaction.

\section{BIBLIOGRAPHY}

1. Altschule, M. D., and Freedberg, A. S., Circulation and respiration in fever. Medicine, In press.

2. Starr, I., Jr., and Gamble, C. J., An improved method for the determination of cardiac output in man by means of ethyl iodide. Am. J. Physiol., 1928, 87, 450.
3. Winternitz, M., Deutsch, J., and Brüll, Z., Eine klinisch brauchbare Bestimmungs-methode der Blutumlaufszeit mittels Decholininjektion. Med. Klin., 1931, 27, 986.

4. Moritz, F., and D. von Tabora, Ueber eine Methode, beim Menschen den Druck in oberflächlichen Venen exakt $z u$ bestimmen. Deutsches Arch. f. klin. Med., 1910, 98, 475.

5. Van Slyke, D. D., and Neill, J. M., The determination of gases in blood and other solutions by vacuum extraction and manometric measurement. I. J. Biol. Chem., 1924, 61, 523.

6. Fieser, L. F., A new absorbent for oxygen in gas analysis. J. Am. Chem. Soc., 1924, 46, 2639.

7. Christie, R. V., The lung volume and its subdivisions. I. Methods of measurement. J. Clin. Invest., 1932, 11, 1099.

8. Iglauer, A., and Altschule, M. D., The effect of arterial and venous constriction induced by paredrine (p-hydroxy-a-methyl-phenylethylamine hydrobromide) on the lung capacity and its subdivisions. Am. J. M. Sc., 1941, 201, 664.

9. Gibson, J. G., II, and Evelyn, K. A., Clinical studies of the blood volume. IV. Adaptation of the method to the photoelectric micro-colorimeter. J. Clin. Invest., 1938, 17, 153.

10. Griffith, J. Q., Roberts, E., Rutherford, R. B., and Corbit, H. O., Studies of criteria for classification of arterial hypertension. III. Cutaneous lymphatic flow. Am. Heart J., 1941, 21, 62.

11. Fremont-Smith, F., Morrison, L. R., and Makepeace, A. W., Capillary blood flow in man during fever. J. Clin. Invest., 1929, 7, 489.

12. Hewlett, A. W., The effect of room temperature upon the blood flow in the arm, with a few observations on the effect of fever. Heart, 1910, 2, 230.

13. Johnson, C. A., Osborne, S., and Scupham, G. W., Studies of peripheral vascular phenomena. IV. The effect of artificial fever on the pulse volume changes of the finger. Am. J. M. Sc., 1935, 190, 485.

14. Meldolesi, G., Studio clinoco della pressione capillare nei suoi rapporti con la pressione arteriosa e con la pressione venosa. Cuore e Circuolaz., 1926, 10, 20 and 45.

15. Scully, F. J., The reaction after intravenous injections of foreign protein. J. A. M. A., 1917, 69, 20.

16. Chasis, H., Ranges, H. A., Goldring, W., and Smith, H. W., The control of renal blood flow and glomerular filtration in normal man. J. Clin. Invest., 1938, 17, 683.

17. Perera, G. A., Clinical and physiologic characteristics of chill. Arch. Int. Med., 1941, 68, 241.

18. Gibson, J. G., II, and Kopp, I., Studies in the physiology of artificial fever. I. Changes in the blood volume and water balance. J. Clin. Invest., 1938, 17, 219.

19. Mendelson, W., On the renal circulation during fever. Am. J. M. Sc., 1883, 86, 380. 
20. Himwich, H. E., Bowman, K. M., Goldfarb, W., and Fazekas, J. F., Cerebral metabolism during fever. Science, 1939, 90, 398.

21. Stead, E. A., Jr., and Kunkel, P., Influence of the peripheral circulation in the upper extremity on the circulation time as measured by the sodium cyanide method. Am. J. M. Sc., 1939, 198, 49.

22. Anderson, G. K., Evaporation of body water in lobar pneumonia. J. Clin. Invest., 1938, 17, 331.

23. Barr, D. P., Cecil, R. L., and Du Bois, E. F., Clinical colorimetry. XXXII. Temperature regulation after the intravenous injection of proteose and typhoid vaccine. Arch. Int. Med., 1922, 29, 608.

24. Kahn, R. H., Ueber die Erwärmung des Carotidenblutes. Arch. f. Anat. u. Physiol., Supp., 1904, 90, 81.

25. Heymans, J. F., Iso-, hyper- et hypothermisation des mammifères par calorification et frigorification du sang de la circulation carotido-jugulair anastomosée. Arch. Int. de Pharm. et de Therap., 1921, 25, 1.
26. Moorhouse, V. H. K., Effect of increased temperature of the carotid blood. Am. J. Physiol., 1911, 28, 223.

27. Heymans, C., and Ladon, A., La tête du chien isolée et hyperthermisée. Compt. rend. Soc. de biol., 1925, 92, 455.

28. To be published.

29. Goldring, W., Chasis, H., Ranges, H. A., and Smith, H. W., Effective renal blood flow in subjects with essential hypertension. J. Clin. Invest., 1941, 20, 637.

30. Smith, H. W., Chasis, H., Goldring, W., and Ranges, H. A., Glomerular dynamics in the normal human kidney. J. Clin. Invest., 1940, 19, 751.

31. Landis, E. M., Micro-injection studies of capillary blood pressure in human skin. Heart, 1930, 15, 209.

32. Ranson, S. W., Clark, G., and Magoun, H. W., The effect of hypothalamic lesions on fever induced by intravenous injection of typhoid-paratyphoid vaccine. J. Lab. and Clin. Med., 1939, 25, 160. 